\title{
Economic Growth and the Optimal Size of the Public sector in Jordan
}

http://doi.org/ 10.21272/fmir.4(3).72-79.2020

Jameel A. Aljaloudi, ORCID: https://orcid.org/0000-0002-2924-4119

Professor, Department of Planning and Project management, College of Business. Al-Balqa Applied University, Jordan

Taleb A. Warrad, ORCID: https://orcid.org/0000-0003-2233-0636

Department of Business Economics, School of Business, the University of Jordan, Amman -Jordan

\begin{abstract}
The relationship between the size of public sector and the rate of economic growth has been widely examined empirically in different countries. Most applied studies confirmed the validity of the inverse relationship between the increasing role of the state in the economy, measured by the ratio of public spending to gross domestic product and rates of economic growth. These studies estimated the optimum rate that would guarantee achieving the highest economic growth rates. This study aims to analyses this relationship for the case of the Jordanian economy. Using a theoretically justified econometric model, the researchers have utilized an ARDL econometric technique to quantitatively assess this relationship for the period (1970-2018). The study relied on official data related to the gross domestic product published by the Central Bank of Jordan and official data related to public spending and public revenues published by the Jordanian Ministry of Finance. The econometric results of the study confirm the existence of an inverse relationship between the size of public sector and the rate of economic growth in Jordan, which may lend support to the hypothesis of the Armey curve. The optimal size of the government (public sector) is estimated to be about 26 percent, which is much lower than the actual average government size in Jordan. The researchers recommend the need to gradually cutting down the size of public sector through adjusting the real spending structure and restructuring the independent public institutions. The restructuring of independent public institutions requires the abolition of institutions that are not economically feasible and constitute more financial burdens on society on the one hand, and the merging of a number of them into an independent public institution that provides its services to the community in an efficient and effective manner. Researchers also recommend the need to continue privatizing the public sector and activating the role of partnership between the public and private sectors
\end{abstract}

Keywords: size of public sector, government spending, economic growth, ARDL, privatization.

JEL Classification: H11, C22, F63, F6.

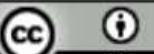

Cite as: Aljaloudi, J. A., Warrad, T.A. (2020). Economic Growth and the Optimal Size of the Public sector in Jordan. Financial Markets, Institutions and Risks, 4(3), 72-79. http://doi.org/ 10.21272/fmir.4(3).72-79.2020.

(C) The Authors, 2020. This article is published with open access at Sumy State University.

\section{Introduction}

The Jordanian Constitution emphasizes the need for the state to intervene in the economy in order to promote it and achieve employment opportunities and thus work to continuously improve the level of well-being of the Jordanian society. Accordingly, the Jordanian governments have increased the public spending (in dinars) and also (the ratio of public spending to GDP) over the past decades, which has led to a growing role of the state in the national economy and in turn the role of the private sector has declined. This increase in the role of the state in the economy has resulted in a number of economic problems, such as the inflation of the government apparatus in terms of increasing the number of independent ministries and public institutions and increasing the number of its employees (administrative sagging), the low level of productivity of the public sector and its competition for the private sector on sources of financing, and increasing the tax burden on citizens and increasing indebtedness. All of which have been reflected in the slowdown in economic growth rates and the rise in unemployment in Jordan (2010-2018). 
This prompted the previous Jordanian governments to reconsider the role of the state in some economic sectors and implement the privatization programs in Jordan since 1998, but its privatization swelled in the country's economy, as evidenced by the increase in the number of independent public institutions to (66) units (www.pm.gov.jo) and their average annual expenditure of 1.81 billion dinars during the period (2009-2019). The ratio of public spending to GDP increased also from $(37.1 \%)$ to $(42.9 \%)$ during the same period. It is also noted that official and popular pressures are increasing to reconsider the size and performance of the public sector, which is the government's attempt to restructure the public sector and integrate a number of public institutions, and to demand civil society institutions and opinion-makers to abolish independent public institutions and control and rationalize public spending. The issue of the optimal size of the public sector in the economy has attracted the attention of researchers at the theoretical and practical level in the world. In 1995, Armey found an inverse relationship between public spending as a proportion of GDP and economic growth rates. He mentioned that any size exceeds the optimal size will slow the rate of economic growth. The research aims to determine the relationship between the government size and economic growth in Jordan. It aims also, to estimate the optimal government size, which ensures that the rate of economic growth in Jordan is maximized.

The researchers relied on official data published by the Central Bank, the Ministry of Finance and the General Statistics Department during the period (1970-2018). They also adopted scientific references and research to formulate the standard model adopted. They developed a standard model of the relationship between the public spending and economic growth rates based on the Army Model, 1995. The Least Robust Squares method was selected to estimate the standard model in the light of standard data tests, which included augmented Dickey Fuller and Engle-Granger cointegration test. The research is based on the lack of previous scientific studies on the Jordanian economy that dealt with this inverse relationship between the size of the public sector and the expectations of economic growth and the estimation of the optimal size of the public sector based on a standard model covering a long period of time (1970-2018). In its second chapter, the research will discuss the theoretical framework and previous studies on the necessity of state intervention in economic activities, determining the relationship between the ratio of public spending and economic growth and estimating the optimal size of the state. In chap.3, they discuss the development of public spending (which reflects the extent of state intervention in the economy) and the rates of economic growth in Jordan during the period (19702018), and in chap. 4, they formulate the model and in chp.5 analysis the results and recommendations.

\section{Theoretical framework and previous studies}

\section{1. Theoretical framework}

Economists differed in their view of the role of the state in the economy. As example, the old classical economists with the principle of economic freedom and the rule of the market system emphasize that market forces are the only guarantors of economic balance, full and optimal use of economic resources, as well as the public interest in society by freely seeking their own interests. At the same time, they stress that the state should not interfere in economic activity so as not to adversely affect the adequacy of the economic system in society, but they allowed the state to do only the function of the guard state. Therefore, they believe that the state should have its financial activity neutral and at the lowest possible cost (as low as possible taxes to finance the minimum and necessary public expenditure) and that the principle of a balanced budget (public expenditures equal public revenues). We refer to Ibn Khaldun's, who considered the first thinker of free market economy. He said: "If the Sultan enters the market corrupted the sultan and corrupted the market "" (introduction of Ibn Khaldun, $1377 \mathrm{AD}$ ). Therefore, we find that the ratio of public spending of GDP (an indicator of the extent of state intervention in the economy) was very low in the capitalist countries (market system) at the end of the nineteenth century, estimated in 1880 by $(3.04 \%)$ in the United States of America and (1.08\%) in Japan and $(8.47 \%)$ in Britain and (11.27\%) in Germany (Mauro, P: 2015).

However, the failure of the market system to produce and distribute public goods and services necessary in society (failure to achieve the principle of exception in these goods and services) on the one hand and the successive economic crises in the capitalist economic systems, the most famous of which is the global recession crisis at the end of the $1920 \mathrm{~s}$, on the other hand showed the failure of the free economy system to achieve economic balance, full employment and ensure the equity distribution of income and wealth among the groups of society. This led to the emergence of socialist and communist ideology, which calls for an inclusive role of the state in the economy (absolute interference of the state in the economy). The emergence of Keynesian thought after World War II, which sees the need for state intervention in the economy besides the private sector and without prejudice to the principle of economic freedom, this intervention with the aim of increasing the 
overall demand for goods and services, which in turn leads to the expansion of the total supply of goods and services and the increase of employment in the economy, which leads to the overall balance of the economy and the full employment of economic resources. Politicians in capital and mixed-economy countries (developed and developing countries alike) adopted Keynesian thought as an approach to economic management in their country, which resulted in the increase disposition of the state's role in the continuous increase in public spending, as well as the adoption of the principle of deficit in the public budget, resorting to domestic and external borrowing and increasing taxes in order to finance the state budget deficit. This intellectual and practical approach was reflected in the increase in the size of the state in the economy as measured by the ratio of public spending to GDP, as this percentage increased in all countries of the developed and developing world. For example, in 1980 (50.34\%) in Germany and (50.53\%) in Britain and (36.05\%) in United States and (36.46\% 9 in Japan. This percentage increase was also observed during the period 19001980 in developing countries e.g. in India increased from (7.18\%) to (19.85\%) and in Mexico from (4.71\%) to $(21.06 \%)$ (Mauro, P. etl: 2015).

This continuous increase in the role of the state in the economy has led to the emergence of contemporary economic problems that the economies of countries did not face before, such as the debt crisis, the deterioration of the productivity of state institutions, the marginalization of the role of the private sector, the increase of the tax burden in society, administrative sagging in state institutions (the emergence of disguised unemployment), the spread of financial and administrative corruption and the slowing down of economic growth rates. This led to demands by the new Liberal economists and politicians that the role of the state in the economy should be reduced by privatizing some public sector institutions and activating the role of public-private partnership in the management of the economy, and this is what many countries of the world have done. Any form of review of the role of the state in the economy (the adoption of the privatization approach) must be based on the principle of quality and efficiency in the provision of goods and services in society, in the sense that the sector that produces and distributes goods or service at a lower price and at higher quality is the first to play this role in the economy, so if the private sector is the most efficient, for example, it must be transferred from the public sector to the private sector. Despite this trend in economic thinking and practical application, we note the continued increase in the role of the state in the economy, as we find that the ratio of public spending of GDP continued to increase in all countries during the past years, in 2010 this percentage in Germany $(50.37 \%)$ In Britain (53.45\%) In the United States (45.07\%), Japan (42.46\%), India (31.89\%) and Mexico (28.64\%) ( Mauro, P etl : 2015 ). The increase in the size of the state and its negative impact on economic growth, in addition to the above mentioned economic problems, have become the focus of attention of many contemporary economists, and they have also been interested in discussing the issue of the optimal size of the state in the economy, which determines the size that guarantees maximum economic growth rates. Army concluded in 1995 that the relationship between the government size and economic growth takes the form of an inverted (U).

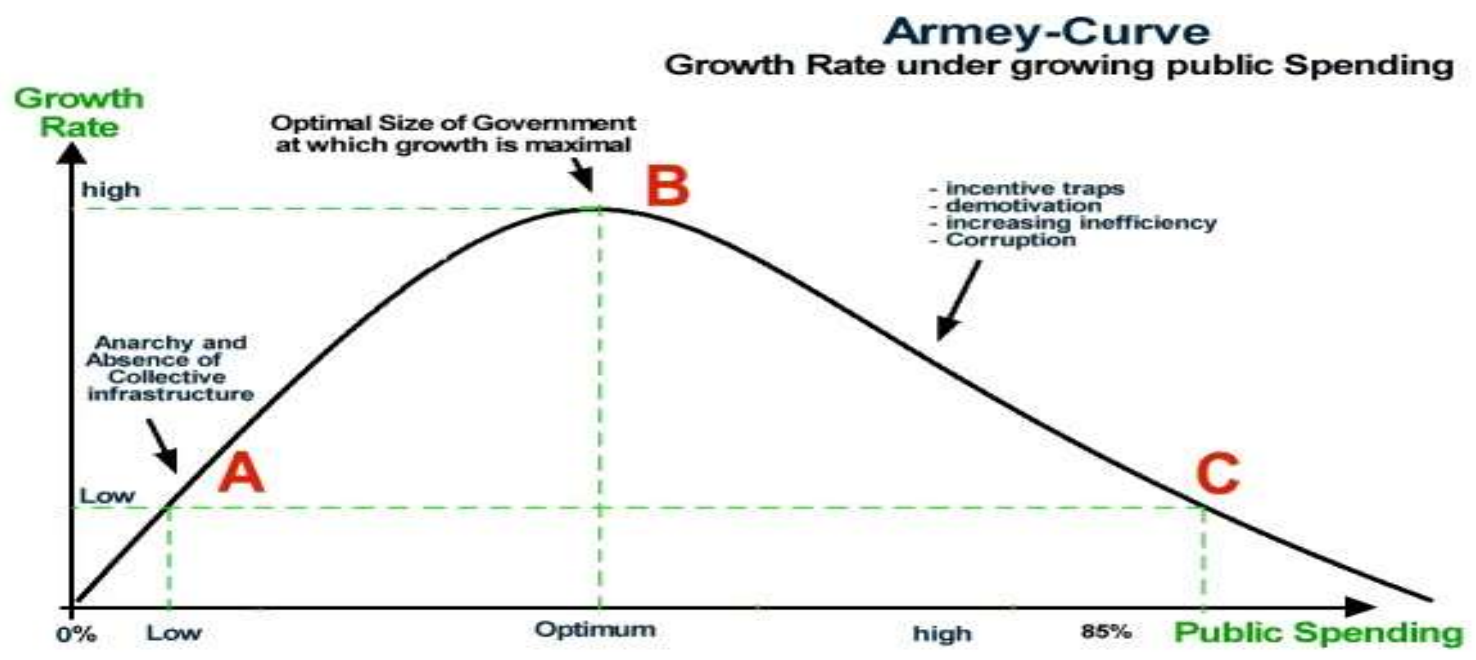

Figure 1. Armey Curve Graph

Source: Richard K. Vedder and Lowell E. Gallaway: Government Size and Economic Growth” Washington, DC $20510,1998$.

Armey believes that if the size of the government is too low and less than point A, it means the absence of a 
government, which means the absence of the law (the law of the jungle) and therefore the absence of security and stability in society. At the same time, he believes that increasing the role of the government from the optimum size at point B leads to the fatigue of the citizen and the investor and to the reduction of individual incentive (increased frustration), and also leads to a decrease in the productive efficiency of public sector institutions and to increase the tax burden on enterprises and individuals in the sectors (business and families), and to increase corruption and indebtedness and thus the negative impact on economic growth (Armey, 1995).

\subsection{Previous studies}

Studies that dealt with the optimal size of the government that would guarantee achieving the highest economic growth rates can be classified into two groups. The first group, which relied on international comparisons for a number of countries at different times (cross section studies). The other group is the one that studied the relationship between the state's role in the economy and its effect on economic growth rates by measuring this relationship in a specific country during a specific period of time (time series studies). Most of the cross section studies confirm the inverse relationship between the size of the government (measured by the ratio of government spending to GDP) and the rate of economic growth, i.e. Proof of Armey's 1995 achievements and compliance in the inverted U. It also e estimated the optimal size of the government, which guarantees the maximum economic growth. The optimal size of government varies among income world groups; it is higher in developed countries (17.88\%) than in developing countries (14.83\%) (Asimakopoulos, and Karavias (2015). Most of the studies adopted the index of government expenditure-to-GDP ratio and economic growth rate to measure the relationship ( Martin and Viega 2014), ( Primož 2013 ), (Rahmayantia and Horn 2011), (Berg and Karlsson 2010) and Afonso and Furceri (2010). The study conducted by Dar and Khalkhali in 2002 and by Foelster and Henrekson in 2001, they used general revenue in addition to public spending to measure impact on economic growth. With regard to applied studies conducted by a number of researchers in only one country and using time series, the data in Table 1 showed the following:

$>\quad$ All field studies except the study conducted by Fallahi.F .etl in year 2012 have proved the validity of Armey's relationship, which is an inverse relationship between the size of the government as measured by the ratio of public expenditure to GDP and the rate of economic growth.

$>\quad$ The estimate of the best size of the government for each of the countries studied in the above studies varied, for example, it was 13.9\% in Italy (Forte and Magzzin 2016), 11\% in Nigeria (Olasode. etl 2014), 17\% in Turkey (Turan 2014) and 22.8\% in Iran (Mehrara and Keikhs 2012). Exception the study of Malaysia, which indicate that the size of government did'nt exeed the optimal size (Riayati and Norashida 2014).

Table 1. Sample of Countries studies (time series)

\begin{tabular}{|c|c|c|c|c|}
\hline The Authors & $\begin{array}{c}\text { Variables of the } \\
\text { studies }\end{array}$ & The sample & Methodology & Results \\
\hline $\begin{array}{l}\text { Forte. F and } \\
\text { Magzzin.C } \\
(2016)\end{array}$ & $\begin{array}{l}\text { A percentage of } \\
\text { public expenitur } \\
\text { and } \\
\text { growth }\end{array}$ & $\begin{array}{l}\text { Italia } \\
(1861-2018)\end{array}$ & $\begin{array}{l}\text { Auto Regressive } \\
\text { Integrated Moving Average } \\
\text { with Exogenous Variables) } \\
\text { models }\end{array}$ & $\begin{array}{l}\text { The inverse relationship between the size of } \\
\text { the government and the rate of economic } \\
\text { growth. The optimal size of government is } \\
\text { estimated at } 13.9 \% \text {. }\end{array}$ \\
\hline $\begin{array}{l}\text { Olasode.S. etl } \\
(2014)\end{array}$ & $\begin{array}{l}\text { A percentage of } \\
\text { government } \\
\text { spending and } \\
\text { economic growth } \\
\text { rate }\end{array}$ & $\begin{array}{l}\text { Nigeria } \\
(1983-2012)\end{array}$ & Least Squares Method & $\begin{array}{l}\text { The inverse relationship between the size of } \\
\text { the government and the rate of economic } \\
\text { growth. The optimum size of the government } \\
\text { is } 11 \% \text {, with a statistical significance of } 0.05\end{array}$ \\
\hline $\begin{array}{l}\text { Riayati, A and } \\
\text { Norashida , O } \\
\text { 2014) }\end{array}$ & $\begin{array}{l}\text { The proportion of } \\
\text { government } \\
\text { spending and the } \\
\text { rate of economic } \\
\text { growth }\end{array}$ & $\begin{array}{l}\text { Malaysia } \\
1970-2012\end{array}$ & $\begin{array}{l}\text { Autoregressive distributed } \\
\text { lag (ARD) }\end{array}$ & $\begin{array}{l}\text { The size of the government did not exceed the } \\
\text { optimal size } \\
\text { It is better to increase government spending to } \\
\text { increase economic growth }\end{array}$ \\
\hline $\begin{array}{l}\text { Turan T. } \\
(2014)\end{array}$ & $\begin{array}{l}\text { The proportion of } \\
\text { government } \\
\text { spending and the } \\
\text { rate of economic } \\
\text { growth }\end{array}$ & $\begin{array}{l}\text { Turkey } \\
(1950-2012) \\
\text { The second period } \\
(1970-2012)\end{array}$ & $\begin{array}{l}\text { Ordinary Least } \text { Squares } \\
(\text { OLS) }\end{array}$ & $\begin{array}{l}\text { The inverse relationship between government } \\
\text { spending and the rate of economic growth } \\
\text { during the two periods } \\
\text { The optimum size varies with the time period } \\
15.4 \% \text { for the period } 1950-2012 \\
17 \% \text { for the period } 1970-2012 \\
\text { This means that the optimum size value } \\
\text { according to Armey is affected by the time } \\
\text { period. } \\
\text { Requesting the Turkish government to reduce } \\
\text { its size in the economy to the optimum size } \\
\text { level that guarantees the maximum economic } \\
\text { growth rate }\end{array}$ \\
\hline
\end{tabular}

Table 1 (cont.). Sample of Countries studies (time series) 
ISSN (online) - 2521-1242 ISSN (print) - 2521-1250

\begin{tabular}{|c|c|c|c|c|}
\hline $\begin{array}{l}\text { Mehrara, M and } \\
\text { Keikhs, A. } \\
\text { (2012) }\end{array}$ & $\begin{array}{l}\text { Government } \\
\text { spending and its } \\
\text { components } \\
\text { And the rate of } \\
\text { economic growth }\end{array}$ & $\begin{array}{l}\text { Iran } \\
(1967-2000)\end{array}$ & $\begin{array}{l}\text { Threshold regression model } \\
\text { to study relationship } \\
\text { between government size } \\
\text { and economic growth }\end{array}$ & $\begin{array}{l}\text { The inverse relationship of total public } \\
\text { spending and its components: } \\
\text { The optimum size for government is: } \\
22.8 \% \text { in relation to total public spending } \\
9.8 \% \text { in relation to investment spending } \\
12.9 \% \text { of consumer spending }\end{array}$ \\
\hline $\begin{array}{l}\text { Fallahi.F and others } \\
\text { (2012) }\end{array}$ & $\begin{array}{l}\text { Government } \\
\text { spending and its } \\
\text { components } \\
\text { And the rate of } \\
\text { economic growth }\end{array}$ & $\begin{array}{l}\text { Greece } \\
(1961-2008)\end{array}$ & $\begin{array}{ll}\text { Smooth } & \text { transition } \\
\text { regression model (STR) }\end{array}$ & $\begin{array}{l}\text { There is no linear relationship between the } \\
\text { size of the government and the rate of } \\
\text { economic growth. Armey's law not being } \\
\text { applied to the Greek economy. }\end{array}$ \\
\hline
\end{tabular}

Sources: compiled by the authors.

This study is considered original because it is the first study that deals with the optimal size of the state in the Jordanian economy. This study comes to answer the size required for the state to play after taking many steps in the field of privatization and activating the role of partnership between the public and private sectors in providing public goods and services, especially. Its importance stems from the fact that it provides a scientific answer to the political decision-maker in the country to determine the required size of the public sector in managing the national economy efficiently and effectively.

\section{Public expenditures and economic growth in Jordan during the period 1970-2018}

Data in Table (2) indicates that the average annual percentage of public spending of the public sector to gross domestic product reached $(40.19 \%)$ during the time period that preceded the economic crisis in 1989 . It also shows the average annual real economic growth rate (4.47) during that period. It was natural for the ratio of public spending to GDP to fall during the period (1990-2008), during which the government implemented economic reform programs, eliminated subsidies on basic commodities, adjusted the tax system, and implemented the privatization program. as this ratio decreased to $(35.38 \%)$. This period witnessed an increase in the annual average of economic growth as it reached (5.32\%) annually.

Despite previous government efforts, the government did not reduce its size during the period (2009-2019). If we take into consideration the expansion of the public sector by establishing new independent public institutions, which numbered 66 in 2019, and whose expenditures are not included in the items of public spending in the general budget. If we add the public spending of these independent institutions to the public spending of the central government, then the percentage of public spending will rise from $(37.5 \%)$ to $(43.68 \%)$ during the time period (2009-2019). At the same time, we find a slowdown in the real economic growth indicators, it estimated (1.65\%) during the same period. (see table 2 )

Table 2. Ratio of public spending to GDP and real economic growth rates in Jordan during the period 19702018

\begin{tabular}{|c|c|c|}
\hline The Period & $\begin{array}{c}\text { Annual average of public spending to GNP } \\
(\%)\end{array}$ & Annual real economic growth (\%) \\
\hline $1970-1989$ & 40.19 & 4.47 \\
\hline $1990-2008$ & 35.38 & 5.32 \\
\hline $2009-2019$ & $37.5(43.68)^{*}$ & 1.65 \\
\hline
\end{tabular}

Sources: 1. Central Bank of Jordan “Annual Reports”. Amman - Jordan. www.cbj.gov.jo; 2. Ministry of Finance; Annual Reports”. Amman-Jordan.www.mof.gov.job; * Include the sending share of independent public institutions.

We conclude from this that there is an inverse relationship between public spending and economic growth rates, as economic growth rates rise at a time when the ratio of public spending to gross domestic product (the size of the public sector in the economy) decreases and growth rates decrease when there is an increase in the size of the state in the economy.

\section{The Model}

The relationship between the size of government and the rates of economic growth remains an area of interest among researchers, both in theory and in practice. In theory, economists agree that there is a direct relationship between the size of the government sector and the total production of the economy, depending on the fact that government spending, both current and capital, is an essential component of total spending and national income. According to the Keynesian multiplier model, increasing government spending not only increases income and total spending, but also increases it by a multiplier that depends on the size of the Keynesian government multiplier, whose value exceeds the correct one. However, this positive relationship does not 
continue indefinitely, as the exaggerated inflation in the volume of government spending compared to the size of private spending will turn the relationship into a competing negative. Where at a certain point, with the continued expansion of public spending, government spending begins to crowd out private spending, particularly investment, and produces what is known as the effect of negative crowding out of private spending or crowding out. This includes an inverted non-linear quadratic u-shaped relationship, which is known as the Armey curve (see Fig. 1). As the relationship begins with a positive, increasing, to a great end, after which the real economic growth rates will decrease. Therefore, it is important for any economy to balance the volume of public and private spending to choose that level of government spending that maximizes real growth rates.

To estimate that volume of the majority of public spending for real growth rates in Jordan (the optimal size for the public sector), the study uses the econometrical analysis to estimate the square relationship between the size of the public sector represented by the ratio of total public spending to gross domestic product (GR) and the real growth rates represented by the annual growth rates in GDP is denominated in constant prices (RGDPG). The study data were taken from the annual statistical bulletins issued by the Central Bank of Jordan and the Ministry of Finance for the period (1980-2017).

To avoid the phenomenon of placebo regression in the time series, the stationary hypothesis of the study variables was started, as it was expected, as expected, using the Augmented Dickey Fuller test that all variables of the model were mono-integral. The next natural next step is to switch to a common integration test. Using the Engle-Granger Cointegration Test, it was found that there is a common integral vector, reflecting the existence of a real balanced relationship in the long term between the real growth variable and other independent variables. In light of the joint integration and the unification of all variables, the ARDL model was used to estimate the long-term Armey relationship represented by the following standard model derived from the Armey model (1995) and used by a very large number of researchers for other countries:

$R G D P G=B 0+B 1 * G R+B 2 * G R 2+U$

Whereas, the variables as previously defined and the variable GR2 indicate squared public spending ratio and the variable $U$ represents random error. In order to avoid the phenomenon of removing important variables from the model, the CLASICAL GROWTH MODEL has been completed by adding relevant variables, including POPG population growth rates, OPEN economic openness, and UNEM unemployment rates. According to the AKAIKE CTETIRIA standard, the optimum slowdown time is set to 2 . Thus, the fully estimated dynamic model becomes the same in equation (2):

$R G D P G=B 0+B 1 * G R+B 2 * G R 2+B 3 *$ Open $+B 4 *$ Unem $+B 5 * P O P G+U$

The ARDL model was estimated using annual data covering the period 1980-2017, and the population growth variable was removed from the final estimation process for the statistically low significance (Greene, 2012). Table 3 shows the results of the estimation of the model represented in equation (2).

Table 3. Result of ARDL estimate for the period 1980-2017

\begin{tabular}{|c|c|c|c|c|}
\hline \multicolumn{2}{|c|}{ Selected Model: ARDL(2) } & & \\
\hline Variable & Coefficient & Std. Error & t-Statistic & Prob. $^{*}$ \\
\hline RGDPG(-1) & -0.169586 & 0.149041 & -1.137849 & 0.2648 \\
\hline RGDPG(-2) & 0.302803 & 0.128870 & 2.349671 & 0.0261 \\
\hline GR & 5.275469 & 2.555425 & 2.064420 & 0.0484 \\
\hline GR2 & -6.923917 & 3.536978 & -1.957580 & 0.0603 \\
\hline OPEN & 0.213224 & 0.056269 & 3.789338 & 0.0007 \\
\hline UNEM & 0.002878 & 0.002458 & 1.171035 & 0.2515 \\
\hline C & -1.123911 & 0.459131 & -2.447907 & 0.0209 \\
\hline R-squared & 0.575368 & Mean dependent var & 0.084908 \\
\hline Adjusted R-squared & 0.484376 & S.D. dependent var & 0.053989 \\
\hline S.E. of regression & 0.038768 & Akaike info criterion & -3.485601 \\
\hline Sum squared resid & 0.042082 & \multicolumn{2}{|c|}{ Schwarz criterion } & -3.174531 \\
\hline Log likelihood & 67.99801 & Hannan-Quinn criter. & -3.378219 \\
\hline F-statistic & 6.323247 & \multicolumn{2}{c}{ Durbin-Watson stat } & 2.018517 \\
\hline Prob(F-statistic) & 0.000272 & \multicolumn{2}{c}{} \\
\hline
\end{tabular}

Source: compiled by authors.

The results of the estimation came in line with the theoretical quadratic relationship represented by equation (2), and the value of the multiple determinant coefficient (58\%) is observed, but this is expected in light of the 
fact that the dependent variable is the rate of growth and the relationship of (2) is not linear. The statistic of the overall morale test for the model indicates a statistical significance of the estimated relationship at a level of significance less than $1 \%$. The evaluation results indicate the stability of the estimated model and the absence of linear self-correlation. The estimated parameters were statistically significant and compatible in terms of the indication with the expectations of economic theory, except for the unemployment variable, which was contrary to the indication but is not statistically significant (high percentage at 25\%) and therefore can be neglected. The parameters of the variables in the field of interest were statistically significant at a level of significance better than $1 \%$ and proportional in terms of signal with the expectations of the Armey curve.

So, this estimation result can be used to answer the central question in the study: What is the rate of public spending that maximizes the real economic growth rate? Taking the first derivative of the estimated relationship and zero equality and calculating the optimal public spending ratio of (3):

$G R=-b 2 / 2 b 3$

Since the parameter in lower case indicates the estimated value.

It is clear that the rate of public spending that maximizes growth is achieved when the ratio of total public spending to GDP is $26 \%$. In view of Table No. (3), which shows the averages of this ratio for the study period, it is clear that this percentage has been significantly exceeded for all periods, which reinforces the prevailing belief that there is inflation in the volume of public spending that reflects negatively on the real growth rates of the Jordanian economy.

\section{Findings and recommendations}

The results of the study indicate that there is a causal relationship of statistical significance between the expansion of public spending and the rates of real economic growth in the Kingdom in general, but that the expansion of public spending to a level higher than required leads to a negative impact on economic growth, reinforced by the existence of the effect of competition between public spending and spending Crowding out effect. The results of the standard analysis show that the ideal public spending rate (i.e. maximizing economic growth) reaches $26 \%$ in the case of the Jordanian economy. In light of the high rates of public spending compared to this percentage in most of the sample years, the study provides evidence of the competition of the public sector for the private sector, which reflected negatively on the real growth rates in the Kingdom. The study recommends introducing structural reforms in the public sector in order to gradually reduce the proportion of public spending to the optimal level required. Perhaps the last steps taken by the government towards restructuring the public sector and merging some ministries and independent institutions are in the right direction if the merger process is real and not formal.

Author Contributions: conceptualization, Alajloudi Jameel; methodology, Alajloudi Jameel and Warrad Taleb A.; validation, Warrad Taleb A.; formal analysis, Alajloudi Jameel and Warrad Taleb A.; investigation, Warrad Taleb A.; resources, Alajloudi Jameel and Warrad Taleb A.; data curation, Alajloudi Jameel; writing - original draft preparation, Alajloudi Jameel; writing - review and editing, Warrad Taleb A; visualization, Alajloudi Jameel; supervision Alajloudi Jameel; project administration, Alajloudi Jameel.

\section{References}

1. Afonso, A., Furceri, D. (2010). Government Size, Composition, Volatility and Economic Growth. European Journal of Political Economy, 26(4), 517-532. Retrieved from: https://papers.ssrn.com/sol3/ papers.cfm?abstract_id $=1699715$

2. Armey, D. (1995). The Freedom Revolution. Washington DC. Regnery. ISBN 978-0-89526-469-5. Retrieved from: https://www.biblio.com/9780895264695

3. Asimakopoulos, S., Karavias. (2015). The impact of government size on economic growth: a threshold analysis. Granger Centre Discussion Paper, 15(2). http://dx.doi.org/10.1016/j.econlet.2015.12.010

4. Bergh, A., Karlsson, M. (2010). Government Size and Growth: Accounting for Economic Freedom and Globalization. Public Choice, 142 (1-2), 195-213. Retrieved from: https://www.jstor.org/stable/40541955

5. Department of Statistic. Annual statistical yearbook (2000-2018). Amman. Jordan. Retrieved from: www.dos.gov.jo 
6. Central bank of Jordan: Summery of the public budget. Amman, Jordan. Retrieved from: www.cbj.gov.jo

7. Central bank of Jordan: Gross National product in constant prices. Amman, Jordan. Retrieved from: www.cbj.gov.jo

8. Dar, A., Khalkhali, S.A. (2002). Government Size, Factor Accumulation, and Economic Growth: Evidence from OECD Countries. Journal of Policy Modeling, 24 (7-8), 679-692. Retrieved from: https://www.sciencedirect.com/science/article/pii/S0161893802001631

9. Fallahi, F., Shoorkchali, J. (2012). Government sixe and economic growth in Greece: A smooth transition approach. Retrieved from: http:/www.econmodels.com/upload7282/6a6balcf08f52069e825ac 968dec 3b06.pdf

10. Fölster, S., Henrekson, M. (2001). Growth Effects of Government Expenditure and Taxation in Rich Countries. European Economic Review, 45(8), 1501- 1520. https://doi.org/10.1016/S0014-2921(00)00083-0

11. Forte, F., Magazzino, C. (2016). Government Size and Economic Growth in Italy: A Time-series Analysis. European Scientific Journal March, 12(7). ISSN: 1857 - 7881 (Print); e - ISSN 1857- 7431. http://dx.doi.org/10.19044/esj.2016.v12n7p149

12. Greene, W. (2012) Econometric Analysis. 7th Edition, Prentice Hall. Retrieved from: https://www.scirp.org/(S(lz5mqp453edsnp55rrgjct55))/reference/ReferencesPapers.aspx?ReferenceID=1679 $\underline{068}$

13. Susana, M., Veiga, F. J. (2013). Government size, composition of public expenditure, and economic development, NIPE working Paper 17/2013. Retrieved from: https://ideas.repec.org/p/nip/nipewp/172013.html

14. Mauro, P., Romeu, R., Binder, A., \& Zaman, A. (2015). A modern history of fiscal prudence and profligacy. Journal of Monetary Economics, 76, 55-70. Retrieved from: https://www.psc.isr.umich .edu/pubs/abs/10012

15. Ministry of Finance. Annual Public Budget (1970-2019). Amman, Jordan. Retrieved from: www.mof.gov.jo

16. Mehrare, M., Keikha, A. (2012). Government size and economic growth in Iran. In Economic Research. ISSN 2229-6-158，32，52-60. Retrieved from: https://www.researchgate.net/scientific-contributions/ 72109248-Mohsen-Mehrara

17. Primoz, P. (2013). Does optimal size of government spending exist. Slovenia. Retrieved from: https://www.researchgate.net/publication/228757512_Does optimal_size of government spending exist

18. Prime Ministry. Retrieved from: www.pm.gov.jo

19. Riayati, A., Norashida, O. (2014). Optimal size of government and economic growth in Malaysia, 9, 4148. ISSN: 2231-962X. Retrieved from: http://www.ukm.my/fep/perkem/pdf// perkem2014/PERKEM 2014 1B2.pdf

20. Vedder, R. K., Gallaway, L. E. (1998). Government Size and Economic Growth. Washington, DC 20510. Retrieved from: https://www.jec.senate.gov/public

21. Romero-Avila, Diego, and Rolf Strauch. (2008). Public Finances and Long-Term Growth in Europe: Evidence from a Panel Data Analysis. European Journal of Political Economy, 24(1), 172-191. Retrieved from: https://ideas.repec.org/a/eee/poleco/v24y2008i1p172-191.html

22. Rousseeuw, P. J., Yohai V. J. (1984). Robust Regression by Mean of S- Estimators, Robust and Nonlinear Time Series Analysis, New York, 256-274, doi: 10.1007/978-1-4615-7821-5-15. Retrieved from: https://link.springer.com/chapter/10.1007\%2F978-1-4615-7821-5_15

23. IbnChaldoon. (2015). Retrieved from: https://ar.wikipedia.org/wiki . 